\title{
Ethno medicinal knowledge of plants used by irula tribes, nellithurai beat, the Nilgiris, Tamil Nadu, India
}

\author{
S M Dhivya', K Kalaichelvi ${ }^{2}$ \\ ${ }^{1}$ Research Scholar, ${ }^{2}$ Associate Professor, Department of Botany, Vellalar College for Women (Autonomous), \\ Thindal, Erode, Tamil Nadu, India
}

Background: The study of local knowledge about natural resources is becoming increasingly important in defining strategies and actions for conservation. In recent years, work in ethnobotanical knowledge worldwide has increased especially in some parts of Europe, Asia, and Africa. India, a country with a rich culture and traditional knowledge, has contributed a major share of the world's ethnobotanical work. Aims and Objectives: The main objectives behind this study was to record the plants used for medicinal purposes in Nellithurai Beat through regular field visits because there is no previous reports on the documentation of medicinal plants from Nellithurai Beat, Karmadai Range, Western Ghats, Tamil Nadu, India. Materials and Methods: An ethnomedicinal survey was conducted from January - 2016 to March - 2016. The information on ethnomedicinal uses of plants was obtained through direct field interviews and designed questionnaire. Their vernacular name, family, mode of preparation and medicinal uses were recorded by interviewing the locals of different age groups. Results: During the present study plant species belonging to 36 families were documented. Of the 40 plant species documented 14 were Shrubs, 12 Trees, 10 Herbs, 3 Climbers and 1 Epiphyte. Leaves and whole plants are the most widely (50\% and $23 \%$ ) used plant part of the reported medicinal plants and decoction are the most widely (48\%) used mode of preparation. Conclusion: The study revealed that tribal community have a great faith in the traditional healing system and they rely on medicinal plants for treatment of various diseases. Due to continuous loss of vegetation, it is necessary that suitability requirements are needed in order to protect the traditional knowledge in a particular area with reference to medicinal plant utilization and the study will be useful for future ethnopharmacological research for the discovery of new drugs.

Key words: Medicinal plants, Nellithurai beat, Indigenous knowledge, Ailments
Access this article online

Website:

http://nepjol.info/index.php/AJMS

DOI: 10.3126/ajms.v7i5.14822

E-ISSN: 2091-0576

P-ISSN: 2467-9100

\section{INTRODUCTION}

Plants are playing an important role in the health of millions of people's life in many villages of India in their day today life by its traditional usage. Herbal medicine is the foundation for about $75-80 \%$ of the world population, mainly targeting primary health care in the developing countries because of better cultural acceptability, compatibility with human body and lesser side effects. However, there is a drastic increase in the usage of herbal medicine was found in last few years from the developed countries. ${ }^{1}$
India is gold mine of practical knowledge on traditional herbal medicines. But unlike China, India has not been able to capitalize on this wealth by promoting its use in the developed world despite their renewed interest in herbal medicines. ${ }^{2}$ It is a country rich in indigenous herbal resources which grow on their varied topography and under changing agro climatic conditions permitting the growth of almost, over 6000 plants which are used in traditional, folk and herbal medicines. But only 3000 plants are medicinally recognized for their value, representing about $75 \%$ of the medicinal needs of the third world countries. ${ }^{3}$ 
Today, continued deforestation and environmental degradation in many parts of India have brought about depletion of medicinal plants and their associated knowledge. ${ }^{4}$ The tribal and rural people of various parts of India are highly depending on medicinal plant therapy for meeting their health care needs. However, valid scientific data on the usage of ethnomedicinal plants is rather obscure. This is attracting the attention of several botanists and plant scientists who directing vigorous researches towards the discovery or rediscovery of several medicinal plants along with their medicinal remedies for various diseases. Several workers were reported the utility of plants for the treatment of various diseases by the different tribal and rural people inhabiting in various regions of TamilNadu. ${ }^{5}$ Therefore, collection of ethnobotanical information and documentation of traditional knowledge has gained prominence from the perspective of drug development. ${ }^{6}$

The main objective of this study was to assess the diversity of ethnomedicinal plants used by Irulas of Nellithurai beat and document the traditional medical practices followed in healing aliments. Therefore, documenting indigenous knowledge through ethnobotanical studies is important for the conservation of biological resources and their sustainable utilization.

\section{MATERIALS AND METHODS}

\section{Study area}

The present study was conducted in Nellithurai beat, Karamadai range, Coimbatore district, Western Ghats, Tamil Nadu during January -2016 to March - 2016. The study area is rich in vegetation and lies between the longitudes $76^{\circ}-53^{\prime \prime}$ and latitudes $11^{\circ}-18^{\prime}$ and has twelve villages with a total area of about $6207 \mathrm{Hec}$. long and it lies at $820-910 \mathrm{msl}$ elevations. Temperature in the area ranges from $21^{\circ} \mathrm{C}$ to $30^{\circ} \mathrm{C}$. The annual average rain fall ranges from 1000 to $1400 \mathrm{~mm}$. The black and red soil, bright sunlight is the two important natural resources abundantly available in this region which are responsible for the development of the vegetation having variable medicinal properties.

\section{Collection of information}

The information on ethnomedicinal uses of plants was obtained through direct field interviews and designed questionnaire with knowledgeable people of the villages and traditional healers. The data regarding names of plant parts used and their method of preparation and mode of administration of various remedies were also noted down. The medicinal value of each plant was enumerated viz., Botanical name, habit, family, vernacular name, parts used, ethnomedicinal uses and mode of action.

\section{Identification}

The plant materials were identified with the help of standard local floras (Flora of Presidency of Madras and Fyson), Preliminary identification was done by examining fresh plants products from the field with the help of villagers. Few respondents were more informative and co-operative. They have shown fresh plants in the habitat, which was useful for the final identification. The identification of plant materials was confirmed with the help of published data.

\section{RESULTS}

\section{Ethnomedicinal survey}

A total of 40 medicinal plants belonging to 36 families were collected simultaneously recording their Vernacular names. These were reported to be used in the cure and treatment of innumerable ailments. Their botanical names, vernacular names, families, part(s) being used, mode of action and medicinal uses are shown in Table 1. Most of the plants are wholly medicinal. The local tribals of Nellithurai beat are using these plants to cure many diseases like Asthma, Jaundice, Tuberculosis, Leprosy, Rheumatism, cough, fever, vomiting, skin diseases, hypertension, wound healing, diabetes, anti inflammation, anti cancerous, etc.,

The families with the largest number of plant species were Acanthaceae, Fabaceae, Euphorbiaceae and Rubiaceae with 2 species each, The remaining plant families had one species each (Table 2). Among the recorded species shrub $(35 \%)$ were found to be dominating over, trees $(30 \%)$, herbs $(20 \%)$, climber $(7.5 \%)$ and epiphyte $(2.5 \%)$ (Table 3$)$.

Analysis of the plant's parts used showed that leaves are the mostly used plant parts (50\%) followed by whole plants $(23 \%)$, root, stem and fruit $(10 \%)$, seeds $(5 \%)$ and gum, tuber and latex (2.5\% each) (Figure 1$)$. The most frequently cited modes of plant used are as decoction (48\%), juice $(15 \%)$, paste $(12.5 \%)$, extraction and tonic $(7.5 \%)$, infusion $(5 \%)$ and raw $(2.5 \%)$ (Figure 2).

\section{DISCUSSION}

Medicinal plants used in the modern healthcare system are, obviously, from the accumulated knowledge on folk medicine of different sources, worldwide. WHO has listed about 21,000 plant species around the world that are used in the healthcare systems. ${ }^{7}$ Among 60,000 flowering plants in India, about 3000 plants are identified to be used as ethno medicine or folk medicine, and of them about 1500 plants are used in Indian Ayurveda, Unani and Siddha system. ${ }^{8}$ 
Table 1: List of Medicinal plants used by the Irula Tribes of Nellithurai beat

\begin{tabular}{|c|c|c|c|c|c|c|c|}
\hline S. No & Botanical name & Habit & Family name & Local name & $\begin{array}{l}\text { Parts } \\
\text { used }\end{array}$ & Medicinal usage & $\begin{array}{l}\text { Mode of } \\
\text { action }\end{array}$ \\
\hline 1. & Abrus precatorius, $L$. & Climber & Fabaceae & Gundumani & $\begin{array}{l}\text { Seed, } \\
\text { leaves }\end{array}$ & $\begin{array}{l}\text { Eyediseases, asthma, } \\
\text { gonorrhea, swellings }\end{array}$ & Decoction \\
\hline 2. & Adenanthera pavonina, $L$. & Tree & Mimosaceae & Coral wood & Leaves & Diarrhea & Juice \\
\hline 3. & Barleria buxifolia, $L$. & Shrub & Acanthaceae & $\begin{array}{l}\text { Kallimullu \& } \\
\text { Rosmullippuntu }\end{array}$ & Leaves & $\begin{array}{l}\text { Respiratory diseases, tooth } \\
\text { ache, joint pains }\end{array}$ & Extraction \\
\hline 4. & Borreria ocymoides, Dc. & Herb & Rubiaceae & Peeli & Leaves & Ring worm and eczema & Decoction \\
\hline 5. & Breynia retusa, $L$. & Shrub & Euphorbiaceae & Perin-nirouri & $\begin{array}{l}\text { Stem and } \\
\text { Leaves }\end{array}$ & $\begin{array}{l}\text { Conjunctivitis, hasten } \\
\text { suppuration }\end{array}$ & Tonic \\
\hline 6. & $\begin{array}{l}\text { Cansjera rheedii, } \\
\text { J.F.Gmel. }\end{array}$ & $\begin{array}{l}\text { Climbing } \\
\text { shrub }\end{array}$ & Opiliaceae & $\begin{array}{l}\text { Kalimanak } \\
\text { keerai }\end{array}$ & Leaves & $\begin{array}{l}\text { Anti diabetes and anti } \\
\text { inflammatory }\end{array}$ & Paste \\
\hline 7. & Capparis grandiflora, Wall. & Shrub & Capparidaceae & Mudkondai & $\begin{array}{l}\text { Pulp and } \\
\text { root }\end{array}$ & $\begin{array}{l}\text { Gastralgia, vomiting, } \\
\text { abdominal pain }\end{array}$ & Decoction \\
\hline 8. & Cereus pterogonus, Lem. & Shrub & Cactaceae & Ooci kalli & $\begin{array}{l}\text { Whole } \\
\text { plant }\end{array}$ & $\begin{array}{l}\text { Purgative, astringent, } \\
\text { constipating, refrigerant, anti } \\
\text { periodic and antipyretic }\end{array}$ & Extraction \\
\hline 9. & Chloroxylon swietenia DC. & Tree & Rutaceae & Purush & Leaves & Wound healing & Decoction \\
\hline 10. & $\begin{array}{l}\text { Cipadessa baccifera, } \\
\text { (Roth.) Miq. }\end{array}$ & Shrub & Meliaceae & $\begin{array}{l}\text { Pullipancheddi } \\
\& \text { savattuchedi }\end{array}$ & $\begin{array}{l}\text { Whole } \\
\text { plant }\end{array}$ & Indigestion & Juice \\
\hline 11. & Crotalaria pallida, Aiton. & Shrub & Fabaceae & Kilukiluppai & Leaves & Vermifuge, fever & Extraction \\
\hline 12. & $\begin{array}{l}\text { Croton bonplandianum } \\
\text { Baill. }\end{array}$ & Tree & Euphorbiaceae & Yeliaamanakku & Leaves & $\begin{array}{l}\text { Cuts and wounds to stop } \\
\text { bleeding }\end{array}$ & Infusion \\
\hline 13. & $\begin{array}{l}\text { Dactyloctenium } \\
\text { aegyptium, (L.) P. Beauv. }\end{array}$ & Herb & Poaceae & Kakkakalpul & $\begin{array}{l}\text { Whole } \\
\text { plants, } \\
\text { seeds }\end{array}$ & $\begin{array}{l}\text { Dysentary, anti inflammatory, } \\
\text { Urinary diseases }\end{array}$ & Extraction \\
\hline 14. & $\begin{array}{l}\text { Decalepis hamiltonii, } \\
\text { Wight \& Arn. }\end{array}$ & Climber & Asclepidaceae & Magalie & Tuber & $\begin{array}{l}\text { Wound healing, fever, } \\
\text { bronchial, asthma. }\end{array}$ & Tonic \\
\hline 15. & $\begin{array}{l}\text { Decaschistia crotonifolia, } \\
\text { Wight. \& Arn. }\end{array}$ & Shrub & Malvaceae & Kallasedi & $\begin{array}{l}\text { Leaves, } \\
\text { root }\end{array}$ & Fever and cough & Decoction \\
\hline 16. & $\begin{array}{l}\text { Diospyrous malabarica, } \\
\text { (Desr.) Kostel. }\end{array}$ & Tree & Ebenaceae & Benson & Fruit & Cold, astringent, anti bacterial & Infusion \\
\hline 17. & $\begin{array}{l}\text { Diplocyclos } \\
\text { palmatus, (Linn.) Jeffrey. }\end{array}$ & Climber & Cucurbitaceae & Shivalingi & Fruits \& & $\begin{array}{l}\text { Jaundice, inflammation and } \\
\text { fever }\end{array}$ & Juice \\
\hline 18. & $\begin{array}{l}\text { Drypetes sepiaria, (Wight } \\
\& \text { Arn.) Pax \& K. Hoffm. }\end{array}$ & Tree & Euphoriaceae & Thanuvam & $\begin{array}{l}\text { Fruit and } \\
\text { bark }\end{array}$ & Fever, diarrhea & Decoction \\
\hline 19. & Ecbolium viride, (Forssk.) & Shrub & Acanthaceae & Nilaambari & $\begin{array}{l}\text { Leaves, } \\
\text { roots }\end{array}$ & Anti inflammatory & Decoction \\
\hline 20. & $\begin{array}{l}\text { Erythroxylon monogynum, } \\
\text { Roxb. }\end{array}$ & $\begin{array}{l}\text { Large } \\
\text { shrub }\end{array}$ & Erythroxylaceae & Devadary & $\begin{array}{l}\text { Wood } \\
\text { and bark }\end{array}$ & $\begin{array}{l}\text { Stomachic, diaphoretic and } \\
\text { diuretic }\end{array}$ & Infusion \\
\hline 21. & Ficus carica, $L$. & Tree & Moraceae & Simaiyattai & $\begin{array}{l}\text { Bark, } \\
\text { leaves, } \\
\text { shoot }\end{array}$ & $\begin{array}{l}\text { Anti-inflammatory, throat } \\
\text { infection }\end{array}$ & Decoction \\
\hline 22. & $\begin{array}{l}\text { Grevillea robusta, } A \text {. } \\
\text { Cunn. }\end{array}$ & Shrub & Proteaceae & Savukkumaram & Leaves & $\begin{array}{l}\text { Antibacterial, antifungal and } \\
\text { anti-inflammatory }\end{array}$ & Decoction \\
\hline 23. & $\begin{array}{l}\text { Hemionitis arifolia, } \\
\text { (Burm.F.) }\end{array}$ & Herb & Cheilanthaceae & Chakuliya & Leaves & $\begin{array}{l}\text { Anti diabetes anti } \\
\text { inflammation }\end{array}$ & Decoction \\
\hline 24. & $\begin{array}{l}\text { Holoptelea integrifolia } \\
\text { Planch. }\end{array}$ & Tree & Ulmaceae & Bachi & $\begin{array}{l}\text { Stem } \\
\& \text { Bark }\end{array}$ & Anti inflammatory & Decoction \\
\hline 25. & $\begin{array}{l}\text { Ixora arborea, Roxb.ex } \\
\text { SM. }\end{array}$ & $\begin{array}{l}\text { Small } \\
\text { shrub }\end{array}$ & Rubiaceae & Vedchi & $\begin{array}{l}\text { Whole } \\
\text { plant }\end{array}$ & $\begin{array}{l}\text { Diarrhea, nausea, cough, } \\
\text { asthma, wounds and sores. }\end{array}$ & Paste \\
\hline 26. & $\begin{array}{l}\text { Jasminum trichotomum, } \\
\text { B. Heyneex Roth. }\end{array}$ & $\begin{array}{l}\text { Climbing } \\
\text { shrub }\end{array}$ & Oleaceae & Parumalli & $\begin{array}{l}\text { Whole } \\
\text { plant }\end{array}$ & Analgesic, antipyretic & Decoction \\
\hline 27. & Kyllinga triceps, Rohb. & Herb & Cyperaceae & Veluttanirbasi & Leaves & Antidiabetics & Juice \\
\hline 28. & Leucas Longifolia, Hk.f. & $\begin{array}{l}\text { Large } \\
\text { shrub }\end{array}$ & Lamiaceae & Irana-peri & $\begin{array}{l}\text { Whole } \\
\text { plant }\end{array}$ & $\begin{array}{l}\text { Hypertension, cough, } \\
\text { headaches, fever, cough. }\end{array}$ & Decoction \\
\hline 29. & Ludwigia peruviana,(L.) H. & Herb & Onagraceae & Kattukkirampu & $\begin{array}{l}\text { Whole } \\
\text { plants }\end{array}$ & $\begin{array}{l}\text { Dysentery, purgative, } \\
\text { vermifuge }\end{array}$ & Decoction \\
\hline 30. & Odina Wodier Roxb. & Tree & Anacardiaceae & Odayam. & $\begin{array}{l}\text { Plant and } \\
\text { Bark } \\
\text { Gum } \\
\text { Stem } \\
\text { and bark }\end{array}$ & $\begin{array}{l}\text { Used to treat leucorrhoea, eye } \\
\text { diseases used in the } \\
\text { treatment of ulcers } \\
\text { Used for treating bruises, } \\
\text { sprains } \\
\text { Used as a remedy for wounds }\end{array}$ & Decoction \\
\hline 31. & $\begin{array}{l}\text { Passiflora leschenaultia, } \\
\text { Dc. }\end{array}$ & Shrub & Passifloraceae & & Leaves & Blood pressure, diabetes & Decoction \\
\hline
\end{tabular}




\begin{tabular}{|c|c|c|c|c|c|c|c|}
\hline S. No & Botanical name & Habit & Family name & Local name & $\begin{array}{l}\text { Parts } \\
\text { used }\end{array}$ & Medicinal usage & $\begin{array}{l}\text { Mode of } \\
\text { action }\end{array}$ \\
\hline 32. & Pedalium murex, & Herb & Pedaliaceae & Yanai nerunjil & $\begin{array}{l}\text { Whole } \\
\text { plants }\end{array}$ & $\begin{array}{l}\text { Puerperal diseases, digestive } \\
\text { tonics, ulcer }\end{array}$ & Juice \\
\hline 33. & Physalis minima, $L$. & Herb & Solanaceae & Kupanti & Leaves & Laxative, abdominal troubles & Juice \\
\hline 34. & Plumbago zeylanica L. & Herb & Plumbaginaceae & $\begin{array}{l}\text { Chithiramoolam } \\
\text { (or) Venkodiveli }\end{array}$ & All parts & $\begin{array}{l}\text { Piles, diarrhoea, leprosy and } \\
\text { jaundice }\end{array}$ & Paste \\
\hline 35. & $\begin{array}{l}\text { Pterolobium indicum } \\
\text { A.Rich. }\end{array}$ & $\begin{array}{l}\text { Small } \\
\text { tree }\end{array}$ & Caesalpiniaceae & Indumullu & Root & $\begin{array}{l}\text { Used in fever, spermicidal } \\
\text { activity }\end{array}$ & Decoction \\
\hline 36. & Salvadora persica, $L$. & Tree & Salvadoraceae & Uka & Leaves & Antiplaque, analgesic & Tonic \\
\hline 37. & Santalum album L. & Tree & Santalaceae & Sandhanam & $\begin{array}{l}\text { Leaf and } \\
\text { Stem }\end{array}$ & $\begin{array}{l}\text { Gastric irritability, dysentery, } \\
\text { Skin diseases, gonorrhea }\end{array}$ & Paste \\
\hline 38. & Scurrula parasitica, $L$. & Parasite & Loranthaceae & - & Leaves & $\begin{array}{l}\text { Reduce swelling, lower blood } \\
\text { pressure, liver diseases }\end{array}$ & Decoction \\
\hline 39. & Strychnos nux-vomica, L. & Tree & Loganiaceae & Yetti & $\begin{array}{l}\text { Stem, } \\
\text { bark }\end{array}$ & $\begin{array}{l}\text { Stomach pain, dysentery, } \\
\text { fever, cold }\end{array}$ & Decoction \\
\hline 40. & Triumfetta pilosa, Wall. & Shrub & Tiliaceae & Ottupulla & Leaves & Antidiabetes and anti oxidant & Decoction \\
\hline
\end{tabular}

\begin{tabular}{|c|c|c|c|c|}
\hline S. No & Family name & $\begin{array}{l}\text { No. of } \\
\text { species }\end{array}$ & Percentage & $\begin{array}{c}\text { Total no. of } \\
\text { species }\end{array}$ \\
\hline 1. & Acanthaceae & 2 & 5 & 40 \\
\hline 2. & Anacardiaceae & 1 & 2.5 & 40 \\
\hline 3. & Asclepiadaceae & 1 & 2.5 & 40 \\
\hline 4. & Cactaceae & 1 & 2.5 & 40 \\
\hline 5. & Caesalpiniaceae & 1 & 2.5 & 40 \\
\hline 6. & Capparidaceae & 1 & 2.5 & 40 \\
\hline 7. & Cheilanthaceae & 1 & 2.5 & 40 \\
\hline 8. & Cucurbitaceae & 1 & 2.5 & 40 \\
\hline 9. & Cyperaceae & 1 & 2.5 & 40 \\
\hline 10. & Ebenaceae & 1 & 2.5 & 40 \\
\hline 11. & Erythroxylaceae & 1 & 2.5 & 40 \\
\hline 12. & Euphorbiaceae & 2 & 5 & 40 \\
\hline 13. & Fabaceae & 2 & 5 & 40 \\
\hline 14. & Lamiaceae & 1 & 2.5 & 40 \\
\hline 15. & Loganiaceae & 1 & 2.5 & 40 \\
\hline 16. & Loranthaceae & 1 & 2.5 & 40 \\
\hline 17. & Malvaceae & 1 & 2.5 & 40 \\
\hline 18. & Meliaceae & 1 & 2.5 & 40 \\
\hline 19. & Mimosaceae & 1 & 2.5 & 40 \\
\hline 20. & Moraceae & 1 & 2.5 & 40 \\
\hline 21. & Oleaceae & 1 & 2.5 & 40 \\
\hline 22. & Onagraceae & 1 & 2.5 & 40 \\
\hline 23. & Opiliaceae & 1 & 2.5 & 40 \\
\hline 24. & Passifloraceae & 1 & 2.5 & 40 \\
\hline 25. & Pedaliaceae & 1 & 2.5 & 40 \\
\hline 26. & Plumbaginaceae & 1 & 2.5 & 40 \\
\hline 27. & Poaceae & 1 & 2.5 & 40 \\
\hline 28. & Proteaceae & 1 & 2.5 & 40 \\
\hline 29. & Rubiaceae & 2 & 5 & 40 \\
\hline 30. & Rutaceae & 1 & 2.5 & 40 \\
\hline 31. & Salvadoraceae & 1 & 2.5 & 40 \\
\hline 32. & Sapindaceae & 1 & 2.5 & 40 \\
\hline 33. & Scorphulariaceae & 1 & 2.5 & 40 \\
\hline 34. & Solanaceae & 1 & 2.5 & 40 \\
\hline 35. & Tiliaceae & 1 & 2.5 & 40 \\
\hline 36. & Ulmaceae & 1 & 2.5 & 40 \\
\hline
\end{tabular}

In the present study 40 plants belonging to 36 families were identified with their medicinal uses. Similar ethnobotanical studies have been reported in several

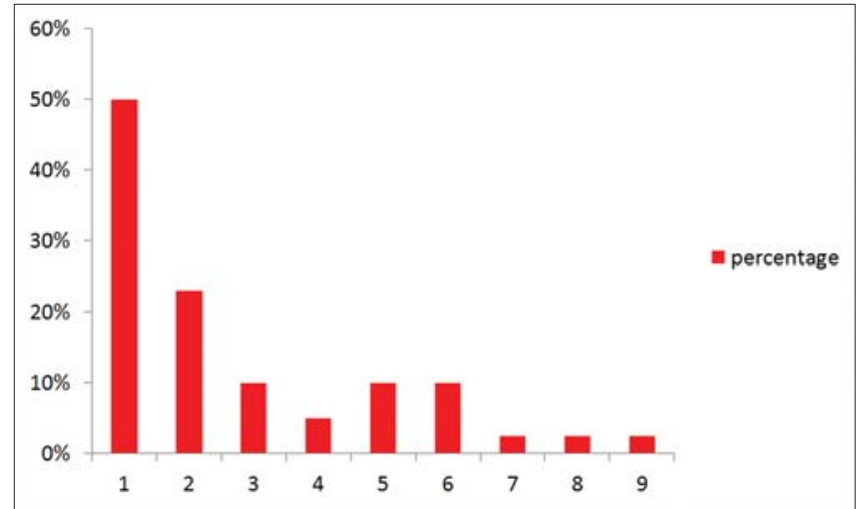

Figure 1: Histogram showing the percentage of parts used

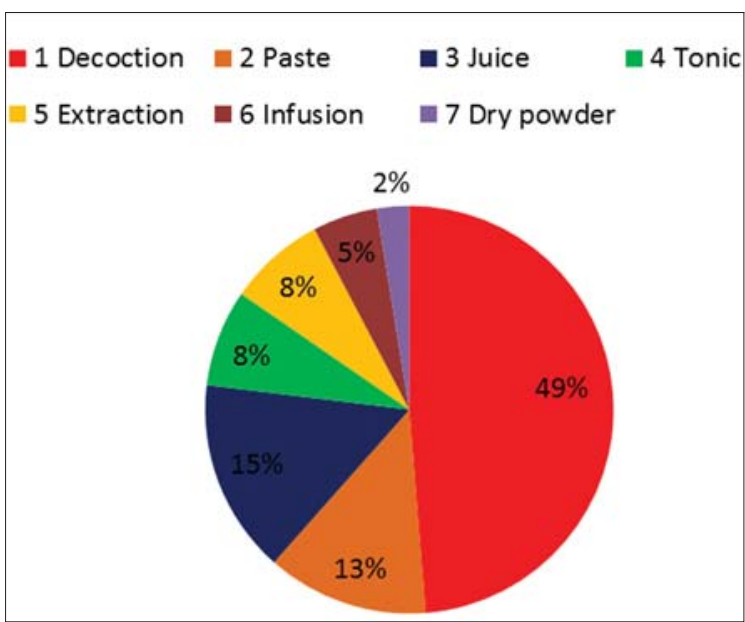

Figure 2: Pie diagram showing the mode of action of ethnomedicinal plants

parts of India to document the traditional knowledge that has been vanishing. ${ }^{9-12}$ Indigenous knowledge of folk is the important sources of locating bio-resources of the locality. The people have been using plant remedies against various ailments from time immemorial without 


\section{Table 3: Analysis of the data based on habit}

\begin{tabular}{llccc} 
S. No & Habit & $\begin{array}{c}\text { Number of } \\
\text { species }\end{array}$ & Percentage & $\begin{array}{c}\text { Total no. of } \\
\text { species }\end{array}$ \\
\hline 1. & Shrubs & 14 & 35 & 40 \\
2. & Trees & 12 & 30 & 40 \\
3. & Herbs & 10 & 20 & 40 \\
4. & Climbers & 3 & 7.5 & 40 \\
5. & Epiphytes & 1 & 2.5 & 40 \\
\hline
\end{tabular}

knowing their effective constituents. ${ }^{13}$ This finding of common medicinal plant families in the study is in agreement with that of previous findings. ${ }^{14}$ Among the recorded species shrub $(35 \%)$ were found to be dominating over other forms. ${ }^{15}$ Analysis of the plant's parts used showed that leaves are the mostly used plant parts in the study area. The recent ethno botanical studies confirmed that leaves are the major portion of the plants used in the treatment of diseases. ${ }^{16,17}$ It is important to highlight that such a wide harvesting of leaves and seeds, compared to roots which are important for survival of plants, has a less negative influence on the survival and continuity of useful medicinal plants and hence does not affect sustainable utilisation of the plants. ${ }^{18}$

In a nutshell, scientific validation of identified plants will established their importance in treatment of various ailments this will also encourage the native people to cultivate these plants as a sources of income in addition to the preservation and conservation of these plants. Further, it has been observed that the traditional practitioners are the custodian of this traditional knowledge and they have their own reservation to pass on this unwritten traditional knowledge to their next generation. Hence, proper method must be adopted to document this traditional knowledge of the local practitioners.

\section{CONCLUSION}

The medico-botanical survey of the area revealed that the people of the area possessing good knowledge of herbal drugs but as the people are in progressive exposure to modernization, their knowledge on traditional uses of plants may be lost in due course. So it is important to study and record the uses of plants used by different tribes for future study. Such studies may also provide some information to biochemists and pharmacologists in screening of individual species.

\section{REFERENCES}

1. Mali PY and Bhadane VV. Ethno-medicinal wisdom of tribals of Aurangabad district (M.S.), India. Indian J Nat Prod Resour 2011; 2(1): 102-109.

2. Ragupathy S, Newmaster SG, Maruthakkutti M, Velusamy B and Ul-Huda MM Consensus of the 'Malasars' traditional aboriginal knowledge of medicinal plants in the Velliangiri holy hills, India. Journal of Ethnobiology and Ethnomedicine 2008; 27(4): 8-15.

3. Chitravadivu C, Manian S and Kalaichelvi K. Middle. East Journal of Sceintific Research 2009; 4 (3): 144.

4. Abraham Z. Glimpses of Indian Ethno botany, Oxford \& Publishing Co., New Delhi, 1981; 308.

5. WHO. WHO traditional medicine strategy. Geneva: World Health Organization; 2002.

6. Rajan S, Sethuraman M and Mukherjee PK. Ethnobiology of the Nilgiri Hills, India. Phytotherapy Research 2002; 16, 98-116.

7. Yusuf M, Begum J, Hoque MN and Chowdhury JU. Medicinal plants of Bangladesh.Chittagong, Bangladesh: BCSIR. 2009.

8. Chaudhary A and Singh N. Contribution of world health organization in the global acceptance of Ayurveda. J Ayurveda Integr Med 2011; 2: 179-186.

9. Ganesan S, Suresh N and Kesavan L. Ethnomedicinal survey of lower Palani Hills of Tamil Nadu. Indian Journal of Traditional Knowledge 2004; 3(3): 299-304.

10. Ignacimuthu S, Ayyanar $M$ and Sankara Sivaraman K. Ethnobotanical investigations among tribes in Madurai District of Tamil Nadu (India). Journal of Ethnobiology and Ethnomedicine 2006; 2: 25-30.

11. Sandhya B, Thomas S, Isabel $W$ and Shenbagarathai R. Ethnomedicinal plants used by the Valaiyan community of Piranmalai Hills, Tamil Nadu, India - A pilot study. African Journal of Traditional, Complementary and Alternative Medicines 2006: 3(1): 101-114.

12. Shanmugam $S$, Kalaiselvan $M$, Selvakumar $P$, Suresh $K$ and Rajendran K. Ethnomedicinal plants used to cure diarrhoea and dysentery in Sivagangai district of Tamil Nadu, India. Int J Res Ayur Pharm 2011; 2 (5): 991-994.

13. Selvadurai S, Shri Vijaya Kirubha T, Senthamarai R and Dutty Roy S. Asian J.Biochem Pharm Res 2013; 3: 116.

14. Shanmugam S, Rajendran $\mathrm{K}$ and Suresh $\mathrm{K}$. Traditional uses of medicinal plants among the rural people in Sivagangai district of Tamil Nadu, Southern India. Asian Pacific Journal of Tropical Biomedicine 2012; S429-S434.

15. Yigra G. Ethnobotanical study of medicinal plants in and around Almata, Southern Tigray, Northern Ethiopia. Curr Res J Bio Sci 2010; 2(5): 338-344.

16. Jeyaprakash K, Ayyanar M, Geetha KN and Sekar T. Traditional uses of medicinal plants among the tribal people in Theni district (Western Ghats), Southern India. Asian Pac J Trop Biomed 2011; 20-S25.

17. Rahmatullah M, Al-Mahmud A, Rahman MA, Uddin MF, Hasan M, Khatun MA, et al. An ethnomedicinal survey conducted amongst Folk medicinal practitioners in the two Southern districts of Noakhali and Feni, Bangladesh. American-Eurasian Journal of Sustainable Agriculture 2011; 5: 115.

18. Sajib $\mathrm{NH}$ and Uddin SB. Ethnomedicinal study of plants in Hathazari, Chittagong, Bangladesh. Tropical Agricultural Sciences 2015; 38(2): 197-210. 